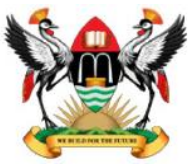

East African School of Higher Education Studies \& Development
Makerere Journal of Higher Education

ISSN: 1816-6822; 7 (2) (2015) $133-146$

DOI: http://dx.doi.org/10.4314/majohe.v7i2.9

(C) The Author(s) 2015

Reprints \& permission: EASHESD

http://ajol.info/majohe

\title{
Educational Ergonomics in Higher Education Institutions in Nigeria
}

\author{
Uche C. M. ${ }^{1, *}$, Okata Fanny C. ${ }^{1}$ \\ ${ }^{1}$ University of Port Harcourt [* Corresponding author: nezenwam@yahoo.com]
}

\begin{abstract}
This study focused on investigating the ergonomics and ergonomic considerations of learning environments of higher education institutions (HEIs) in Nigeria. It adopted a descriptive survey design. Population of study comprised all the three universities in Rivers State and a total of 136 lecturers, 230 students and 6 staff of works departments constituted the sample. Four research questions and one hypothesis guided the study. Data was collected using a researcherconstructed questionnaire entitled Educational Ergonomics in Higher Institutions questionnaire (EEIHIQ). An observation checklist and interview schedules were also used. The instrument was validated by experts and its reliability index was established at .75 index using Pearson Moment correlation coefficient. Mean scores were used to answer the research questions while the $\mathrm{z}$-test was used to test the hypotheses at the .05 level of significance. The findings were that school buildings and other teaching and learning facilities in the universities are ergonomically below standard and unsafe. Recommendations towards improvement are made.
\end{abstract}

Keywords: Physical facilities planning; Ergonomics; Quality assurance

\section{$1 \quad$ Introduction}

In the wake of globalization, every aspect of the human life - science and technology, culture, economic, environmental, social and political has undergone tremendous transformation. Education and educational institutions are vehicles that propel the rapidly changing world and its new ideas and demands, and therefore must constantly and continuously undergo changes and improvement both in its curriculum and learning environment. With the explosion of information and global competitiveness, the nature of teaching and learning is rapidly changing in order to remain relevant, competitive and be conformed to the current dispensation. It becomes very necessary and 
imperative therefore for teaching and learning environments to be designed to fit its users - students and lectures, as teaching and learning cannot take place in isolation of an enabling and safe environment.

Ergonomics is that science of making jobs and environment fit the worker or their users. Noe, Hollenbeck, Gerhart \& Wright (2004) define ergonomics as the study of the interface between individual's physiology environments. The goal of ergonomics is to minimize physical strain on the worker (or the users of the environment) by structuring the physical work environment around the way the human body works. Ergonomics focuses on outcomes such as reducing physical fatigue, aches and pains, and health problems. Ergonomics is aimed at engineering products and the environment to meet the comforts and health of the individuals, human beings directly involved in its utilization.

The theoretical framework used for the study is the Normative Theory of Service (NTS) by Bammer (2002) which states that knowledge and tools can be used in producing the service especially for optimizing it or planning improvements to it and these should be made sufficient to workers for maximum productivity. Teaching and learning outcomes can be greatly optimized in the higher institutions of learning if the facilities, equipment, buildings and the likes are adequately provided and improved upon by designing them in such a way that they fit the health and safety of its users ergonomics. When this is so, productivity in terms of quality of outcomes will be greatly enhanced. Educational ergonomics requires that the school administrator provides environment that will suit teaching and learning processes as well as ergonomically consider the health and comfort of the key players and its users - lecturers and students.

Education, as has been widely accepted by nations all over the world is the bedrock of national development. The higher institutions are the nation's manpower development storehouses where the dreams and aspirations of a nation especially like Nigeria is being translated into realistic goals and being actualized. The objectives of education can only be achieved in a comfortable and safe teaching and learning environment. Teaching and learning environments in higher institutions must be designed in such a way that it matches the capabilities, limitations and the needs of the users. A lecture room with no seats, no lecture, highly placed chalkboards, where the lecturer will have to constantly strain to write on it, broken ceilings and leaking roofs of buildings, inadequate lighting provisions, unpolished floors with rough and cracked surfaces, poorly ventilated classrooms, lack of toilet facilities etc. does not conform to ergonomic standards and not safe for use by the users as it will affect their physical health conditions. When work environments are ergonomically designed in such a way that the safety and health of the employees or the users are put into consideration, then it will become user friendly and enhance efficiency of work and productivity. 
Quality of teaching learning environments of any institution of learning, in terms of conformance to standard and safety of purpose is a direct determinant of the quality of the products or graduates from such institutions. According to Ebong (2006), the standard of the environment in which teaching and learning take place helps to determine the progress of failure of the school endeavour. If the quality is high, it will manifest in the products (graduates) and if not, it will reflect on them. Quality in teaching and learning environment refers to the elemental components; physical, internal, social and son on, and in terms of physical, it relates to classrooms, libraries, workshops, lecturers offices etc. The environment in which teaching and learning process takes place can determine the satisfaction derived by students, teachers, parents and the general public.

The International Ergonomics Association (IEA) divides ergonomics into three broad domains: physical ergonomics, cognitive ergonomics and organizational ergonomics. Physical ergonomics is concerned with human anatomical issues such as workplace layout, working posture, safety and health issues. The cognitive ergonomics is concerned with mental processes and handless issues like mental workload, decision making, skilled performance, human - computer interaction, stress etc. while organizational ergonomics deals with issues on socio - technical systems such as organizational structure, policies and processes (communication, resource, management, quality management, teamwork, workplace design etc.). For the purpose of this work, educational ergonomic which is the science of applying ergonomics to education, will be considering only the domain of physical ergonomics of learning environments of higher institutions in Nigeria with focus of on those in Rivers State (Southern part).

Ergonomics is concerned with the 'fit' between people and their technological tools and the environment. It considers the user's capabilities and limitations in ensuring that tasks, equipment, information and the environment suit the user. The study reviews the state of teaching and learning facilities their status and conformance to ergonomics and to identify areas of non conformance with a view to addressing it so that the objectives of higher education can be achieved. Odejele (2002) observed that in Nigeria, there is poor maintenance culture, hence facilities in most of the schools located across the country are in dysfunctional state. According to him, there is need to maintain school facilities in such a way that they will not constitute hazards to the health of the teachers and learners. Onyekwelu (2002) opined that the educational industry is one of the largest sub-sectors in Nigeria economy and so government cannot fold her arms and watch the existing structures in the educational system collapse. From the foregoing, teaching and learning facilities are of critical importance in education and for it to be functionally effective it must be designed to fit the users in order to encourage students to be willing to learn and the lectures to be able and willing to teacher. When 
conditions of work as regards to health hazards are not considered, as well as safety conditions and provisions, the users will be discouraged and the willingness to teach and study gradually diminishes. This is because matters of health and comfort are of prior importance to a man.

Hanushek (2009) observes that some schools in the third world attract better teachers when they create a more pleasant and safe work environment. Good ergonomics can be used as a strategy to remain best workers, boost morale and even enhance productivity. Ergonomics can help reduce cost by improving safety (International Ergonomics Association, 2000). Pleasant work environments includes environment where the amenities provided for teaching and learning meet their specified needs and serve their purposes to enhance teaching and learning in a safe and healthy way. Teachers in such environment put in their best, learners optimize their abilities, productivity is consequently increased, and educational objectives are attained quicker. Ergonomics is aimed at re - engineering products and the environment to meet the comforts of the teacher and learner. Ergonomically considerations are about determining the extent to which the comfort of teachers and learners can help them achieve the objectives of Education.

In the present age of globalization, educational systems all over the world are re-designing and transforming both in content and context and making their education more relevant and competitive to be able to fit into the global environment. Ergonomics works to minimize physical strain on the worker by structuring the physical environment round the way the human body works. The design of chairs and desks to fit posture requirements is very important in teaching and learning places particularly in the classrooms, offices, laboratories, libraries etc. Giving ergonomic consideration to school environment reduces number and severity of communicative trauma disorders (injuries that result from performing the same movement over and over), lost production time and restricted duty days. The environment where teaching and learning process takes place needs not be just conformable but also meets the physical and health needs of the teachers and students. When this is not so, excuses, absenteeism, turnover, as well as health challenges become the order of the day. Examples of ergonomic considerations in design of teaching learning facilities include adjusting the height of a computer keyboard in a computer laboratory which minimizes the occupational injuries such as carpal tunnel syndrome. Inadequate lighting systems in halls and classrooms, offices, laboratories, increased unwise levels of machine in workshops and near buildings where teaching and learning process takes place, can result to health problems of the eyes and ears respectively.

When the educational environments and its facilities become health threats probably due to their design or their present state of dilapidation and disrepair, teaching and learning process cannot take place. When teachers have to suffer 
from ill - health resulting from their work environment, and students find it difficult to learn effectively due to the poor state of facilities, the educational process suffers. No wonder, the brain drain syndrome affecting the institutions of higher learning in the country. Environmental designs to suit the needs of professional users needs a combination of all professionals e.g. in education the teacher, learner, architect and planners should be involved (Altaman 1975). Zeisel (1975) identified user needs to be: "Those characteristics required of an environment to permit the completion of activities planned typically, undertaken in a special setting".

In playing, the ergonomics contribution an expert advice is needed and very importantly, to identify user needs so that the system recognizes and gives consideration for these user needs and the physical factors that influence them.

Agu and Shonekan (1997) regretted the prevalence of poor teaching and learning facilities, inadequate accommodation and ill - equipped laboratories. Chukwuemeka (2000) opines that science teachers in Nigeria are dissatisfied with facilities available for the performance of their task. Uche, Okoli and Ahunanya (2011) found out that the infrastructural development in higher institutions is of low quality and not student friendly. Inadequate working materials, poorly designed and unsafe laboratories and workshops, lack of basic facilities, seats, tables, equipment, inadequate space as well as large class sizes have become a common observation in higher institutions of learning. The possible result of this state of affairs is poor achievement in science and technology and turning out of graduates who cannot meet up with society's needs and demands. McVey (1989) states that teaching/learning environments must be designed in such a way that learning may proceed with minimum stress and maximum effectiveness. This study therefore focused on the ergonomics and ergonomic considerations of learning environments of the three higher institutions in Rivers State (One University of Education, one specialized University and one traditional university).

\subsection{Statement of the Problem}

If the teaching/learning environment lacks proper planning and ergonomic consideration from the onset, educational goals will not be achieved. Teaching and learning process can only be enjoyable when the available facilities are adequately safe and suitable for the users. It is therefore imperative that ergonomics of teaching and learning facilities consideration and standards are strictly adhered to in planning, implementation and maintenance of the facilities. This study therefore investigated the ergonomics and ergonomic considerations of learning environments of the higher institutions in Rivers State of Nigeria. The main areas of focus addressed were: the ergonomically safety considerations of school buildings and teaching - learning facilities; the 
safety provisions made; the regularity of maintenance services available for the learning facilities; the extent to which the facilities are fit for the users in the higher education institutions.

\subsection{Purpose of Study}

The main purpose of this study was to examine the ergonomics and ergonomic considerations of higher institutions in Nigeria, with focus on Rivers State. Specifically, the study was conducted to investigate.

1. The ergonomically safety considerations of school buildings and teaching learning facilities.

2. The safety provisions available in the building and learning facilities?

3. The regularity of maintenance services available for the learning facilities.

4. The extent to which the facilities are fit for the users in the higher institutions.

\section{$1.4 \quad$ Research Questions}

1. How ergonomically safe are the school buildings and teaching learning facilities in the Institution

2. What are the safety provisions available in the building and learning facilities?

3. How regular are the maintenance services available to the learning facilities?

4. To what extent are the facilities fit for the users in the higher institution?

\subsection{Hypothesis}

There is no significant difference in the mean ratings of male and female students on how safe the buildings and learning facilities are in the institutions.

\section{$2 \quad$ Methodology}

The study adopted a descriptive survey design. The aim is to describe the current status of ergonomics and ergonomic considerations of teaching learning environments in higher institutions of learning. The population of the study comprised all the three universities in Rivers State - one University of Education, one specialized University and one Traditional University. About 370 lecturers, 2300 final year students from the Faculties of Education, Humanities/Arts and Engineering, as well as 60 staff of the works department of the three Universities were used to generate the data. A total of number of 
people used was 2730 out of which 372 were selected as sample size of the respondents, which is about $20 \%$ of the entire population. A simple random sampling technique and purposive balloting were used in selecting the sample of the respondents. Out of the 372 respondents, there were 136 lecturers, 230 students and 6 staff of works department constituted the sample size for generating data. The instruments used for the study include a 25 item questionnaire titled Educational Ergonomics in Higher Institutions Questionnaire (EEHIQ), Checklist Observation and Interview schedule. Content validity of the instruments was carried out by experts in the field while the reliability was tested using the Pearson Product moment correlation-coefficient at 0.75 reliability index. Instrument was administered by the researcher and a return rate of $93 \%$ was recorded. Mean scores and $\mathrm{z}-$ test were the statistical tools used to analyse data at 0.05 significant - level.

\section{$3 \quad$ Results}

Research Question 1: How ergonomically safe are the school buildings and teaching learning facilities in the Institution?

Table 1: Mean scores on Ergonomic Safety of Facilities in the Institutions

\begin{tabular}{lcccc}
\hline \multirow{2}{*}{ Facility } & \multicolumn{2}{c}{ Lecturers } & \multicolumn{2}{c}{ Students } \\
& Mean & Remarks & Mean & Remarks \\
\hline School buildings & 2.41 & Unsafe & 2.38 & Unsafe \\
Classroom blocks and lecture halls & 2.51 & Safe & 2.46 & Unsafe \\
Lecturers offices & 2.40 & Unsafe & 2.18 & Unsafe \\
Laboratories & 3.10 & Safe & 2.24 & Unsafe \\
Engineering workshops & 2.44 & Unsafe & 2.33 & Unsafe \\
Library & 2.48 & Unsafe & 2.42 & Unsafe \\
Computer rooms & 2.30 & Unsafe & 2.25 & Unsafe \\
Toilets (conveniences) & 2.26 & Unsafe & 1.36 & Unsafe \\
Work benches and tables & 2.41 & Unsafe & 2.18 & Unsafe \\
Classroom environment & 2.65 & Safe & 2.55 & Safe \\
Machines and Equipment rooms & 2.44 & Unsafe & 2.27 & Unsafe \\
Language studies & 2.53 & Safe & 2.58 & Safe \\
Stairways and walkways & 2.36 & Unsafe & 2.42 & Unsafe \\
Hostel accommodation & 2.36 & Unsafe & 2.15 & Unsafe \\
ICT centre & 2.46 & Unsafe & 2.30 & Unsafe \\
Grand mean & 2.43 & Unsafe & 2.27 & Unsafe \\
\hline
\end{tabular}

Table 1 shows the mean ratings of responses of lecturers and students on the safety of buildings and learning facilities. From the result of the analysis, it was revealed that items $1,3,5,6,7,8,9,13$, and 15 were considered ergonomically 
unsafe by both lecturers and students while items 2,4 and 10 were considered safe. This shows that buildings, computer rooms, library work benches and tables, machine and equipment rooms, ICT Centre, engineering workshops are all in ergonomically unsafe conditions for use by students and lecturers.

Research Question 2: What are the safety provisions available in the learning facilities of the institution?

Table 2: Safety provisions in the facilities observed

\begin{tabular}{|c|c|c|}
\hline Attributes & $\%$ & Remarks \\
\hline $\begin{array}{l}\text { Classroom Ergonomics (space seat and seating } \\
\text { arrangement, location, lighting, colour, chalkboard, } \\
\text { projector, noise -level lecture, ventilation (etc.) }\end{array}$ & $43 \%$ & $\begin{array}{l}\text { Not } \\
\text { Adequate }\end{array}$ \\
\hline $\begin{array}{l}\text { Laboratory ergonomics (dark room, furnaces, fume } \\
\text { cupboards, windows, work benches and table tops, air - } \\
\text { condition, fans fire extinguisher, ventilation storage } \\
\text { facilities for chemicals, lighting, noise -level, seats, } \\
\text { etc.). }\end{array}$ & $56 \%$ & $\begin{array}{l}\text { Moderately } \\
\text { Adequate }\end{array}$ \\
\hline $\begin{array}{l}\text { Workshop ergonomics (hard - hat safety shoes, coveralls, } \\
\text { gloves, goggles, ear - muffs, ventilation fire fighting } \\
\text { equipment, emergency exists etc.). }\end{array}$ & $48 \%$ & $\begin{array}{l}\text { Not } \\
\text { Adequate }\end{array}$ \\
\hline $\begin{array}{l}\text { Library settings and ergonomics (location, easy access, } \\
\text { display settings, noise - level, ventilation, convenience, } \\
\text { lighting, colour, seat arrangements, space ancillaries } \\
\text { etc.) }\end{array}$ & $63 \%$ & $\begin{array}{l}\text { Very } \\
\text { Adequate }\end{array}$ \\
\hline $\begin{array}{l}\text { Others (lecturer's offices, conveniences, space, lighting } \\
\text { walkways, stars, computer rooms, ICT centres, audio - } \\
\text { visual aids etc.) }\end{array}$ & $60 \%$ & $\begin{array}{l}\text { Very } \\
\text { Adequate }\end{array}$ \\
\hline
\end{tabular}

Table 2 presents of analysis from observation schedule of various safety provisions and ergonomic considerations of various parts of the institutions as it touches teaching and learning facilities. Results showed that classroom and worked shop ergonomics and safety provisions have the least percentage scores of $48 \%$ while the library ergonomics settings and safety provisions was the highest with $63 \%$. This was followed loosely by category (lectures offices No 20 item with $60 \%$. Laboratory ergonomics has a percentage score of $56 \%$ from the above results, it was revealed that classroom ergonomics was not adequate, meaning that the safety provisions and ergonomic considerations actually falls below standard. Other percentage scores revealed that their safety provisions were either moderately adequate or very adequate.

From the interviews, responses received revealed a similar result as the one observed above. Provisions for safety and ergonomic considerations were as 
observed with the observation schedule. However, interviews also revealed a similar result as the one observed above. Provisions for safety and ergonomic consideration were as observed with the observation schedule. However, awareness of safety and safety procedures or even the term ergonomics, safety gadgets and equipment when available are over - used.

Research Question 3: How regular are the maintenance services available to the learning facilities?

Table 3: Regularity of maintenance of facilities

\begin{tabular}{lll}
\hline Facilities & Mean & Remarks \\
\hline Buildings, classrooms, lecture halls & 2.43 & Not regular \\
Laboratories and its settings & 2.69 & Regular \\
Workshops and its settings & 2.41 & Not Regular \\
Library & 3.13 & Very Regular \\
$\begin{array}{l}\text { Others (offices, conveniences, lighting, walkways, } \\
\text { stairs, computer room, ICT centres, audio-visual } \\
\text { aids) }\end{array}$ & & \\
\hline
\end{tabular}

Results of data analysis in Table 3 shows that classrooms, lecture halls and buildings as well as workshops and other categories of facilities do not enjoy regular maintenance services. This is evident in their mean scores of 2.34, 2.41 and 2.46 respectively. The laboratories and libraries show regular maintenance services wit mean ratings of 2.69 and respectively. The laboratories and libraries show regular maintenance services with mean ratings of 2.69 and 3.13 respectively.

Research Question 4: To what extent are the facilities fit for the users in the higher institutions?

Table 4: Fitness of facilities for their purpose

\begin{tabular}{lll}
\hline Facilities & Mean & Remarks \\
\hline Buildings, classrooms, lecture halls & 2.21 & Not fit \\
Laboratories and its settings & 2.57 & Fit \\
Workshop and its settings & 2.36 & Not fit \\
Library & 2.75 & Fit \\
Others (lectures' offices, conferences, lighting space, & 2.33 & Not Fit \\
stairs, walkways, ICT centres and audio-visual rooms) & & \\
\hline
\end{tabular}

Table 4 shows that teaching facilities such as classrooms, workshops and lecturers' offices are not fit for users (see items 26, 28 and 30 with low mean 
scores). However the result reveals that laboratories and libraries are fit for user (items 27 and 28 with high mean scores).

Research Hypothesis 1: There is no significant difference in the mean ratings of male and female students on the ergonomic safety of school buildings and teaching - learning facilities.

Table 5: Mean difference in scores on the ergonomic quality of facilities

\begin{tabular}{llllllll}
\hline Gender & $\mathrm{N}$ & Mean & S.D & DF & Z - Cal & Z - Critical & Decision \\
\hline Male & 142 & 2.43 & 1.42 & 228 & 1.32 & 1.96 & Accepted \\
Female & 88 & 2.31 & 1.38 & & & & \\
\hline \multicolumn{7}{l}{ 0.05 Level of Significant }
\end{tabular}

Table 4 presents the $\mathrm{z}$ - test difference of the mean scores of male and female students on the safety of school buildings and facilities. The result shows that there is no significant difference between the mean scores of male and female students at 0.05 alpha level of significance. This is evident in the fact that the $\mathrm{z}$ - calculated value of 1.32 is less than the critical value of 1.96 at 228 degree of freedom. Hence the null hypothesis is accepted while the alternative is rejected. Therefore there is no significant difference between the mean scores of male and female students on the ergonomic safety of school buildings and learning facilities.

\section{Discussion}

Research question one sought to find out how ergonomically safe the buildings as well as the teaching and learning facilities in higher institutions of learning under study were. Findings revealed that majority of the buildings and teaching and learning facilities were in an unsafe condition in ergonomic terms. These include the classrooms, lecture halls, offices, workshops, computer rooms, conveniences amongst others. This shows that the facilities do not conform to ergonomic standards. Teaching and learning facilities take place under ergonomically unsafe environments. A situation where educational activities cannot effectively take place due to the state of the environment cannot lead to high productivity or the realization of educational goals. This finding is supported by a statement of report of the committee on vision 2010 (1997):

At tertiary level, education has experienced phenomenal expansion without a proportionate increase in funding and facilities. The system suffers from problems such as outdated, dilapidated or non - existent infrastructure, poorly stocked libraries, inadequate laboratories, poor conditions of services prompting main drain". 
The state of infrastructure as well as teaching - learning facilities in the institution of higher learning cannot be delineated from the politics behind the establishment of most of them. Educational objectives of the tertiary level of education can only be achieved when the teaching and learning environment and facilities are structurally and functionally designed to meet the comfort and health demands of the users.

The study also revealed that most part of the teaching and learning facilities, do not enjoy ergonomic consideration and provisions for safety were inadequate. From the results and their percentage scores it was evident that must of the facilities do not conform to ergonomic standards. Again, this is an issue that can gravely affect the outcome of educational endeavours, it will adversely affect performance as users begin to develop one health challenge after another. This problem can be avoided if an ergonomics approach is given to the design from the onset. This finding is supported by the findings at an ergonomics event conference, NZES 2010. Some benefits were identified when user centred approach is applied to the design of learning environments. These include: lower injury and accident rates, faster learning times, fewer errors, easier maintenance, a general increase in job satisfaction, less absenteeism, increases in productivity amongst others. In line with this, Pooja and Remul (2006) observed that to sustain a workforce, it has become important to ensure a hazard free and safe working environment and it has been embraced by managers that a safe working environment can result in greater efficiency and productivity. However Fasasi (2009:183) disagrees with this view by stating that a poorly motivated manager or school leadership and not necessarily ergonomic considerations of teaching - learning environments, constitute a cog in the wheel of progress and in the achievement of educational objectives.

The findings of this research also revealed that gross lack of regular maintenance of facilities and infrastructures account for their present poor states some of the buildings and facilities may have been given ergonomic considerations in their design at the initial time, but overtime due to over-use and lack of proper and regular maintenance, has been rendered unsafe for use, this finding was supported by the findings of Asiabake (2008) who stated in the study conducted to find out the effectiveness of school facilities, that physical facilities in schools are not fully utilized due to poor maintenance and inadequate facility planning. According to him, poor plant planning brings about reduction in educational quality and contributes to students' poor academic achievement. Findings also show that there was no significant difference between male and female students on the ergonomic safety of school buildings and learning facilities. The implication of this is that the treatment and perception of both groups on the issue were the same. This finding is not consistent with "Safe Building Alliance" memo a non-governmental 
organization memo (273/2006), which revealed that all education buildings should be so designed in such a way that prevents injuries to staff and students and also provides the safest environment for them to teach and acquire their learning property. The sight of some of the buildings and facilities are scary as most of them are in very terrible looking state with classrooms looking bare and empty. No seats, leaking roofs, rough fence, inadequate lighting broken windows and doors, no seats and desk or tables, overcrowding and the likes are some of the features of these buildings and facilities. Physical observation also revealed that very few functional buildings and an array of uncompleted or dilapidated or abandoned building projects. The few completed ones have become poor in shape probably due to over-use or over-stretched as a result of over-population. A classroom or lecture hall meant to sit 30 and 50 students now is forced to take 150 students and above, no seating facilities, the few available ones have either no tables, nor is it broken down with exposed jagged and sharp metallic edges or surfaces posing threat of injury to the users. Facilities like equipment furniture, laboratories, workshops, libraries, audiovisual rooms, computer rooms, projector rooms, lecturer's offices etc. vary in quality and standard. Yet, these are institutions of higher learning where the economic and development goals of the country are expected to be realized in terms of manpower production.

\section{Conclusion}

The Ergonomic consideration of physical teaching and learning facilities constitutes major determinants in the success of teaching and learning. It is therefore very pertinent that priority be given to the provision of proper environment so that the key factors in the educational processes can effectively play their roles. Educational objectives cannot be achieved in an unsafe environment with teaching learning facilities that are detrimental to the health of its users. Teaching and learning cannot take place in an environment whose facilities are not designed to "fit its users" in regards to their health and physical well-being. The teaching-learning facilities in the tertiary institutions in Rivers State as the findings of this research revealed are not ergonomically conformed in terms of standard and specifications and the facilities suffer from lack of maintenance.

\section{Recommendations}

1. The government and planners should ensure that appropriate and pragmatic strategies are adopted in higher institutions to improve on the teaching and 
learning environments and particularly to see to it that facilities are conformed to ergonomic standards.

2. The government should allocate more funds and resources to the universities to enable expansion of facilities, repair and maintenance of already existing but dilapidated infrastructure and facilities and to ensure that safety provisions and procedures are made and adhered to in laboratories and workshops. All necessary places and facilities should be regularly maintained by the institutional leadership.

3. Training and awareness programmes should be organized by school an administrator for staff and students on ergonomics issues as it pertains to their jobs and usage of the learning facilities. Best practices should be encouraged.

4. Ergonomic experts should be consulted by the administrators, to identify ergonomic issues that hampers on employees job and the student's effective learning. Appropriate programmes and intervention should be employed.

5. The concept of public and private partnership in maintenance should be explored in the maintenance effort of the institutions.

\section{References}

Asiabake, I.P (2008). The need for effective management of schools in Nigeria. New York Science Journal (10.21). Retrieved from http://www.sciencepub.org/newyork/1020/02-0366-AsiabakafacilitiesPDF.

Agu, A. A. \& Shonekan, S. (1997). An Overview of the Nigerian University System: University System News, Abuja National University Commission.

Benner, J.R. (2002). Lighting for school Washington, D.C. National Clearing house for Educational Facilities. Retrieved 10/08/2014 from http//www/.edafcilitiesorg/pubs/lighting.Html.

Chukwuemeka, S.S. (2000). Adoption, diffusion implementation and institutionalization of educational innovations. In R. Ruser \& J.V. Dempsey (Eds.) Trends \& Issues in Instructional Design and Technology. Upper Saddle River. N.J: Prentice - Hall.

Ebong, J.M. (2006). Understanding Economics of Education. Port Harcourt: Eagle Lithograph place.

Fasasi, Y.A. (2009). Management behaviour in educational organizations. In J.B. Babalola \& A.O. Ayeni (Eds.). Educational Management: Theories and tasks. (183 - 194). Macmillan Nigeria Publishers.

Hanushek, L.N (2009). Lighting for schools Washington D.C: National Clearing house for Educational Research. Retrieved 12/08/2014 from http://www.edfacilities.org/pubs/lighting:html. 
http://en:wikipediaorg/wiki/Ergonomicsretrieved10/08/2014.

International Ergonomics Association (IET) August 2000.

International Labour Organization (ILO) May 2010.

McVey, G.P (1989). Learning Environment in International Encyclopaedia of Educational Technology. Oxford: Bergamot Press, pp. $124-131$.

Onyekwelu, B.A. (2002). Teacher and Teaching. Harmondsworth: Bengin Books Ltd.

Pooja, \& Remul, R (2006). New model of Job design, motivating employees' performance, Journal of Management Development, Volume 26, Page 575 583.

Safe Building Alliance Memo "Non - Governmental Organization Memo (273/2006): Retrieved October $10^{\text {th }}$, 2010 from http://en.wikipedia.org/wiki/change.

Uche, C. M., Okoli, N. J. \& Ahunanya, S (2011). Infrastructural Development and Quality Assurance in Nigerian Higher Education. Journal of Emerging Trends in Educational Research and Policy Studies. Vol. 2, No. 1. February 2011. 9-16. 